\title{
Idea naukowości Henri Poincarégo
}

\section{Nauki matematyczno-przyrodnicze na przełomie XIX i XX wieku}

Okres XVIII i XIX wieku jest czasem fascynacji nowożytnym przyrodoznawstwem. W oparciu o fizykę Newtona i inne nauki przyrodnicze próbowano zbudować jednolity gmach wiedzy, a przede wszystkim wprowadzić nowy porządek świata (nauka miała usunąć nędzę i wszelkie nierówności społeczne) korzystając z metod i wyników dostarczonych przez te nauki. Świat miał stać się całkiem zrozumiały, a ludzkość dzięki wynalazkom technicznym miała osiągnąć optymalny stan rozwoju, zapewniając wszystkim dobrobyt i szczęście. W drugiej połowie XIX wieku nastąpił gwałtowny rozwoju nauk, zdający się potwierdzać te aspiracje. Niespotykany w dziejach rozwój ma miejsce szczególnie w matematyce. Wchodzi ona na całkiem nowe obszary badawcze, co niesie ze sobą nowe jej rozumienie. Już nie tylko liczba i wielkość jest przedmiotem jej badań (jak rozumiano przez wieki), lecz praktycznie wszystkie kategorie ontologiczne znalazły się w obszarze matematyki. Najbardziej spektakularne jest uczynieniem przedmiotem matematyki nieskończoności aktualnej (teoria zbiorów nieskończonych i liczb pozaskończonych). Otworzyło to pole do jej niemal nieograniczonych zastosowań. Zdawało się, że cały świat zostanie ujęty w struktury pojęć i formuł matematycznych.

Dostrzeżono jednak zarazem, że wiele pojęć i metod, na których opiera się matematyka odbiega od wymogów ścisłości i precyzji. Wiele fundamentalnych pojęć, jak na przykład pojęcie funkcji, ciągłości, gra- 
nicy, zmiennej, nieskończenie małej, liczby, przestrzeni geometrycznej, było rozumianych i używanych w sposób nieścisły oraz intuicyjny. Prowadziło to do wielu sporów i nieporozumień. Rozpoczęto więc badanie podstaw nauki i uściślanie pojęć. Starano się uporządkować przede wszystkim podstawy analizy matematycznej, rachunku prawdopodobieństwa, geometrii. Te badania w pewnym stopniu przyczyniły się do pojawienia się nowych teorii matematycznych, w tym teorii mnogości, topologii, teorii szeregów trygonometrycznych, geometrii nieeuklidesowych, teorii grup, teorii funkcji analitycznych czy logiki matematycznej. Rozpoczęto próbę budowy uniwersalnego języka nauki w parciu o logikę matematyczna, teorię mnogości czy algebrę.

Powstają też nowe działy nauk przyrodniczych (w tym termodynamika i elektrodynamika), odbiegające od schematu fizyki nowożytnej. Również one pokazują niewystarczalność klasycznej matematyki i skłaniają do budowy nowych teorii matematycznych (czy rozbudowy starych) jako odpowiednich narzędzi badań i interpretacji poznawanych zjawisk. Nowe teorie doprowadziły też do innego spojrzenia na świat i jego strukturę.

$Z$ jednej stronie następowało coraz większe oddalanie się od siebie nauk matematyczno-przyrodniczych i filozofii. Pojawiła się filozofia "humanistyczna”, która deprecjonowała nauki przyrodnicze oraz ich znaczenie dla egzystencji człowieka. Z drugiej natomiast mamy rozwój pozytywizmu, empiriokrytycyzmu oraz logicyzmu, które znacząco ograniczają dziedzinę filozofii (praktycznie rugując z niej metafizykę). Pojawili się jednak uczeni, którzy posiadając znaczące osiągnięcia $\mathrm{w}$ ramach rozwijających się nauk, poszukiwali również nowych filozoficznych interpretacji rozwoju i struktury nauki, odpowiednio wykorzystując różne dziedziny badań i refleksji. Powstają nowe filozofie matematyki (platonizm Cantora, intuicjonizm Brouwera, logicyzm Fregego i Russela, formalizm Hilberta) oraz fizyki (Ludwig Boltz-mann, Heinrich Hertz, Wolfgang Ostwald).

Przełomowe znaczenie dla dalszej refleksji nad naukami miało wystąpienie jednego z największych uczonych tego czasu, który pracował tak w zakresie matematyki, fizyki jak i filozofii, Henri Poincarégo (1854-1912). Najbardziej intensywny okres jego twórczości przypada na przełom XIX i XX wieku. Podejmuje najtrudniejsze zagadnienia, stosuje nowe metody i teorie matematyczne, między innymi bada zagadnienie stabilności układu słonecznego (problem trzech ciał) stosując metody topologii, dając tym samym podwaliny pod współczesną teorię stabilności. Stosuje też geometrie nieeuklidesowe do badania i rozwiązywania równań różniczkowych, tworzy nową dyscyplinę matematyczną - topologię algebraiczna, a w ramach prób związanych z zachowaniem jedności fizyki przedstawia projekt nowej fizyki (swoją teorię nazywa teorią 
elektronu $)^{1}$. Było to próba unifikacji mechaniki klasycznej z elektrodynamiką Maxwella, zawierająca kilka alternatywnych rozwiązań pojawiających się problemów (jako jedna z alternatyw pojawia się ogłoszona w tym czasie przez Einsteina szczególna teoria względności)². Program unifikacji fizyki Poincarégo nie został podjęty i jest przykładem zapomnianej w nauce teorii, która stanowi jednak ciągły przedmiot refleksji historyczno-filozoficznej.

Podejmuje w końcu refleksję filozoficzną nad historią nauki i jej struktura, tworząc nową koncepcję filozoficzną zwaną konwencjonalizmem. Zastosowana przez Poincarégo nazwa „,konwencjonalizm” prowadziła i prowadzi do wielu nieporozumień. W jego filozofii bowiem zasady fizyki, które mają rangę konwencji, nie są przyjmowane arbitralnie. W ich powstaniu istotną rolę odgrywają tak doświadczenie empiryczne jak i formalizm matematyczny, które mają prowadzić do powstania optymalnie prostej i spójnej teorii. Struktura nauki jest hierarchiczna - u podstaw fizyki tkwi geometria, natomiast geometria jest zbudowana na arytmetyce i algebrze. O ile dobór teorii fizycznych, jak również geometrii jest w pewnym sensie konwencjonalny, to najbardziej podstawowe struktury arytmetyczne i algebraiczne (zasada indukcji matematycznej oraz algebraiczna struktura grupy) są pierwotne, preegzystują w umyśle i stanowią uniwersalny mechanizm wszelkich konstrukcji.

Koncepcje naukowe i myśl filozoficzna Poincarégo miały istotne oddziaływanie. Jego filozofię konwencjonalizmu rozwijał Louis Rougier (1889-1982). Wpłynęła też ona znacząco na twórców empiryzmu logicznego ${ }^{3}$. Traktowano ją jako doskonały przykład filozofii naukowej ${ }^{4}$. Odegrała też znaczącą rolę w budowanej przez Kazimierza Ajdukiewicza koncepcji radykalnego konwencjonalizmu (który w późniejszym okresie złagodził swoje stanowisko, zbliżając się do poglądów Poincarégo).

1 H. Poincaré, Sur la dynamique de l'électron. „Compt. Rend." 1905, nr 140, s. 1504-1508; również w Oeuvres, s. 489-493; rozwija tę teorię w pracy: Sur la dynamique de l'électron, „Rendiconti Circolo math. di Palermo” 1906, nr 21, s. 139-176.

2 J. Gray, Henri Poincaré. A Scientific Biography, Princeton University Press, Princeton and Oxford 2013.

3 H. Reichenbach, H., The Theory of Relativity and A Priori Knowledge, University of California Press, Berkeley 1920.

4 Konwencjonalizm Poincarégo był badany i rozwijany w nurcie logicznego pozytywizmu dzięki Moritzowi Schlickowi oraz Hansowi Reichenbachowi. Również Rudolf Carnap wykorzystywał idee konwencjonalizmu do budowy formalnego języka nauki. Filozofia francuskiego uczonego była jednak niewłaściwie rozumiana i często rozumiano konwencje jako sądy analityczne. Z powodu krytykowania przez Schlicka konwencjonalizmu uogólnionego oraz uznania, że współczesna fizyki nie realizuje założeń konwencjonalizmu, został on w dużym stopniu zdyskredytowany. Przyczynił się do tego też sam A. Einstein, gdy w artykule Geometry and Experience pokazał zasadnicze różnice między filozoficznymi podstawami jego teorii względności a konwencjonalizmem. 
Szczególnie w dyskusjach związanych $\mathrm{z}$ teorią względności, naturą praw nauki, rozumienia czasu i przestrzeni odwoływano się do jego poglądów. Jego poglądy stanowią ważny myśl w nurcie naukowego realizmu i jest on uważany za twórcę realizmu strukturalnego ${ }^{5}$. Był przeciwnikiem logicyzmu, a jego prace na temat twórczości naukowej, roli intuicji w odkryciach naukowych i ukazywanie paradoksów w podstawach nauk zainspirowały nowy nurt badań nad nauką w duchu pragmatyzmu oraz intuicjonizmu. Przykładowo Poincaré uznawał tylko definicje predykatywne i w ten sposób chciał rozwijać teorię mnogości. Z większymi lub mniejszymi przerwami filozofia Poincarégo była cały czas obecna $\mathrm{w}$ filozoficznej refleksji nad nauką. Współcześnie mamy prace Adolfa Grünbauma z 1968, który argumentuje za geometrycznym konwencjonalizmem ${ }^{6}$ czy Roberto Torrettiego ukazującego ważny nurt badań w filozofii geometrii biegnący od Riemmana do Poincarégo ${ }^{7}$. Bardzo ożywione są też dyskusje na temat wkładu Poincarégo w powstanie teorii względności. Również niektóre epistemologiczne rozważania W.V.O. Quine'a mają swoje korzenie w tezach Poincarégo o zależności sensu wyrażeń od konwencjonalnego układu pojęćc

W pracy tej koncentruję się zasadniczo na jednym zagadnieniu idei naukowości, wypracowanej przez tego uczonego. Wyjaśnię, w jaki sposób jego rozumienie nauki odbiega od spojrzenia pozytywistycznego czy skrajnie apriorycznego. Przekracza ono prostą dychotomię między empiryzmem a racjonalizmem. Poincaré był jednym z ostatnich uczonych mających wgląd $\mathrm{w}$ całość nauk matematyczno-przyrodniczych. W późniejszym okresie, wobec ich gwałtowanego rozwoju, powstania nowych teorii, metod i dyscyplin, utraciły one jedność i spójność. Myślę, że koncepcja Poincarégo, poprzez sięganie do najgłębszych struktur poznawczych, pozwala ciągle patrzeć na naukę jako na jedną (złożoną) strukturę. Mimo pewnej liczby prac na temat filozofii nauki francuskiego uczonego, koncepcja nauki Poincarégo jest ciągle mała znana lub rozumiana w niewłaściwy sposób. Pokazuję jej wartość bez wchodzenia w polemiki, koncentrując się na sile argumentów samego Poincarégo. Ponadto pokażę, że na filozofię Poincarégo

5 J. Worrall, Structural Realism: The Best of Both Worlds?, „Dialectica” 1989, nr 43, s. 99-124.

6 A. Grünbaum, Geometry and Chronometry in Philosophical Perspective, University of Minnesota Press, Minneapolis 1968.

7 R. Torretti, Philosophy of Geometry from Riemann to Poincaré, D. Reidel, Dordrecht 1978.

8 Por. G. Heinzmann, D. Stump, "Henri Poincaré", The Stanford Encyclopedia of Philosophy (Spring 2017 Edition), Edward N. Zalta (ed.), https://plato.stanford.edu/ archives/spr2017/entries/Poincaré.

9 W.V.O. Quine, Ontological Relativity and Other Essays, Columbia University Press, New York 1969; Pursuit of Truth, Harvard University Press, Cambridge 1990. 
można patrzeć nie tylko jak na pewną teorię filozoficzna, lecz również jak na ogólną metodę badawczą.

Niniejsza praca jest uzupełnieniem mojej refleksji nad filozofią nauki Poincarégo, którą przeprowadziłem w czterech pracach: Polemiki wokót wkładu Poincaré go na powstanie szczególnej teorii względności $i^{10}$, Pewna interpretacja konwencjonalizmu Poincaré'go ${ }^{11}$, Mechanizm ewolucji fizyki według Poincaré'go ${ }^{12}$, Różne twarze konwencjonalizmu w kontekście sporu o podstawy szczególnej teorii względności ${ }^{13}$.

\section{Wartość nauk matematyczno-przyrodniczych}

Filozofia Poincarégo pojawiła się w okresie dominacji pozytywistycznej interpretacji nauki (w tej interpretacji nauki przyrodnicze jawią się jako całkowicie racjonalny system niezbitych i nieomylnych praw oparty na rzeczywistości nagich faktów) i różnych prób redukcjonistycznych, na przykład sprowadzania matematyki do logiki (logicyzm) czy czystych form, symboli i reguł operowania nimi (formalizm). Filozofia Poincarégo wyraźnie przeciwstawiała się tym interpretacjom nauki, broniła związku nauki z doświadczeniem empirycznym (jednak nie $\mathrm{w}$ duchu pozytywistycznym) i negowała skrajny aprioryzm czy konwencjonalizm. Nie była też jedynie analizą stanu ówczesnych nauk, lecz poprzez analizę historii nauki, nowych metod i teorii naukowych rodzących się w drugiej połowie XIX wieku, dążyła do budowy syntezy - nowa filozofia miała ogarnąć różnorodność nauk, zrozumieć mechanizmy ich rozwoju, obronić jedność nauki, ukazać związek nauki z rzeczywistością i strukturą umysłu oraz przewidzieć tendencje i kierunki jej przemian ${ }^{14}$.

Można uznać, że początek formułowania doktryny konwencjonalizmu miał miejsce w 1887 r., gdy Henri Poincaré, w pracy Sur les hypothèses fondamentales de la géometriée $e^{15}$, przedstawił swoje poglądy na podstawy geometrii, włączając się $\mathrm{w}$ trwającą od dłuższego czasu dyskusję. Jego

10 W. Wójcik, Polemiki wokót wkładu Poincarégo na powstanie szczególnej teorii względności, „Zagadnienia Filozoficzne w Nauce” 1993, t. XV, s. 37-54.

11 W. Wójcik, Pewna interpretacja konwencjonalizmu Poincarégo, „Kwartalnik Filozoficzny" 1993, z. 3, s. 21-43.

${ }_{12}$ W. Wójcik, Mechanizm ewolucji fizyki według Poincarégo, "Przegląd Filozoficzny” 1993, r. II, nr 4, s. 37-52.

13 W. Wójcik, Różne twarze konwencjonalizmu w kontekście sporu o podstawy szczególnej teorii względności, w: Nauka i społeczeństwo w stulecie szczególnej teorii względności Alberta Einsteina (1905-2005) (red. B. Płonka-Syroka), Wrocław 2006.

14 Filozofia nauki Poincarégo w kontekście współczesnego sporu o racjonalność naukową jest omawiana w książce: W. Sady, Spór o racjonalność naukowa. Od Poincarégo do Laudana, Wydawnictwo Naukowe UMK, Toruń 2013, s. 47-80.

${ }_{15} \mathrm{H}$. Poincaré, Sur les hypothèses fondamentales de la géométrie, „Bulletin de la Société Mathématique de France" 1887, t. 15, s. 203-216. 
prace filozoficzne zostały wydane w czterech książkach: Nauka i hipoteza (La science et l'hypothèse, Paryż 1902), Wartość nauki (De valeur de la sience, Paryż 1905), Nauka i metoda (Science et méthode, Paryż 1908) oraz Ostatnie myśli (Dernières pensées, Paryż 1926). Ponadto publikował w różnych czasopismach i prezentował swoje poglądy podczas wielu wykładów, konferencji naukowych i prelekcji.

\section{Sprzeciw wobec antyintelektualizmu. Obiektywność nauki i jej związek z rzeczywistością. Nauka wobec prawdy}

Poincaré ukazuje wartość nauki, jej metodę w dużej mierze w polemice z Le Royem. Według Le Roya fakty naukowe są całkowicie tworzone przez uczonego i to on uznaje dane prawa za prawdziwe lub fałszywe. Są one „[...] konstrukcją symboliczną powstałą przy okazji faktów: jest ono drugim stopniem racjonalizacji rzeczywistości"16. Fakty naukowe są tworzone z faktów (pierwotnych), które też znacznie odbiegają od rzeczywistości (są efektem pierwszego stopnia racjonalizacji zniekształcającej ich realny charakter). Liczba (i ich znaczenie) elementów przypadkowych i podmiotowych, które składają się na dany fakt naukowy jest tak duża, że prawa naukowe, zbudowane na faktach „[...] w sposób absolutny wykraczają poza granice empirii i nie mogą być poddane kontroli obserwacji"17. Do tych elementów nieobiektywnych można zaliczyć: czas, przestrzeń, ruch (jako formy rozumu), wybór jednostek i metod pomiarów, interpretowanie obserwowanych parametrów i wyników zgodnie z oczekiwaniami. Na każdym kolejnym etapie budowy teorii naukowej mamy do czynienia z jej modyfikacją na nieskończenie wiele sposobów i dlatego jej odległość od rzeczywistości się oddala. Teoria naukowa jest tylko chwilową i przypadkową reakcją na bodźce doświadczenia. Nie jest więc prawdziwa, nie można jej udowodnić, a trwa ewentualnie dłużej tylko dzięki temu, że wytwarza więź między umysłami uczonych i daje sposobność prostego mówienia o rzeczywistości.

Poincaré w mocnych słowach odcina się od takiego rozumienia teorii naukowej. Jest ona, według niego, wynikiem postawy nominalistycznej i anty-intelektualistycznej (jak zauważymy w dalszej części Poincaré akceptuje pewną wersję nominalizmu). Poincaré zauważa, że w filozofii Le Roya najprostsza analiza intelektualna rzeczywistości i ubranie jej w słowa sprawia, że rzeczywistość ta znika. „Istotnie, filozofia anty-intelektualistyczna, odrzucając analizę i mowę, tym samym skazuje się na

${ }^{16}$ E. Le Roy, Science et philosophie, „Revue de Métaphysique et de Morale”; tł. M. Zuber, w: K. Szlachcic, Filozofia nauki francuskiego konwencjonalizmu, Wrocław 1994, s. 118.

17 Ibidem, s. 119. 
niezdolność przenoszenia, jest to filozofia zasadniczo wewnętrzna"18. Zastępuje wówczas rozum uczuciem, instynktem i działaniem, traktując sam rozum jako coś pomocniczego i drugorzędnego. To przewartościowanie czynników pozarozumowych w budowaniu nauki jest dla niej, według Poincarégo, bardzo niebezpieczne. Staje się bowiem wówczas podatna na łatwe i bezkrytyczne zmiany. Wypracowywany przez lata język naukowy i metoda wymagają żmudnej intelektualnej pracy i krytycznej ostrożności przy dokonywaniu jakichkolwiek modyfikacji. Pójście za głosem uczuć i chwilowego entuzjazmu może zniszczyć najwartościowsze fragmenty nauki, których ukryte piękno i harmonia ujawnia się dopiero po długich i systematycznych badaniach.

Również nie zgadza się Poincaré z poglądem, że nauka jest jedynie zbiorem reguł, jako pewien rodzaj gry. Reguły stosowane $\mathrm{w}$ grach sa bowiem całkiem dowolne i nie pozwalają na przewidywanie przyszłego stanu rzeczy. Nauka natomiast jest zdolna do predykcji, przez to staje się użyteczną i może być traktowana jako prawidło działania (a nie odwrotnie). A dowodem na jej związek z rzeczywistością jest to, że niektóre przewidywania teorii naukowych się nie sprawdzają. Natomiast pomyłki, których z czasem nauka popełnia coraz mniej, są narzędziem modyfikacji teorii i postępu. W tym momencie wyłania się ważna relacja między działaniem naukowym a poznaniem. Dla Poincarégo, jeśli nauka ma mieć jakąkolwiek wartość, poznanie musi być celem nauki, natomiast działanie naukowe środkiem do tego celu. Produktem ubocznym poznania naukowego i argumentem za ukazanym kierunkiem zależności są zastosowanie techniczne i rozwój przemysłu i wszelka użyteczność nauki - nauka rzeczywiście nawiązuje relacje z rzeczywistościa, poznaje ją i się w nią wpisuje. „Nauka przewiduje, i dlatego właśnie, że przewiduje, może być użyteczną i służyć za prawidło działania"19.

Nauka ma więc dla Poincarégo walor obiektywny. Uczony nie tworzy (całkowicie) faktów naukowych. Jego twórczość sprowadza się do: wyboru odpowiednich faktów (wartych obserwacji), doboru odpowiedniego języka i wyrażenie $w$ nim zaobserwowanych faktów surowych, zestawienie faktów surowych $w$ fakt naukowy. Fakt surowy jest ujęciem doświadczanego zjawiska w nieostrym i nieścisłym języku. Zostaje on potem poddany "obróbce" naukowej, dlatego staje się jako taki częścią teorii naukowej (gdyż teoria naukowa nie jest statycznym efektem pracy uczonego, lecz ciągle poddawana jest udoskonalaniu). Dlatego swoboda działalności uczonego jest wyraźnie ograniczona. Poincaré podaje prosty przykład ukazujący różnicę między faktem surowym a naukowym. Jeśli obserwuję odchylenie galwanometru, widząc przesuwanie się na skali obrazu świetlnego, który powstaje przy pomocy ruchome-

18 H. Poincaré, Nauka i metoda, tłum. M.H. Horwitza, Warszawa 1911, s. 137.

19 H. Poincaré, Wartość nauki, tłum. L. Silberstein, Warszawa 1908, s. 140. 
go zwierciadła, to wówczas faktem surowym jest postrzeganie przeze mnie przesuwania się tego obrazu świetlnego, natomiast faktem naukowym stwierdzenie, że w obwodzie płynie prąd $\mathrm{d}^{20}$. Fakt naukowy jest więc przełożeniem faktu surowego na język danej teorii naukowej. „Fakt naukowy nie jest niczym innym jak faktem surowym przełożonym na język wygodniejszy"21. Język naukowy ułatwia więc wysłowienie faktów i komunikację między uczonymi, natomiast nie ma mocy tworzenia faktów ex nihilo. Wybór języka jest sprawą konwencji, jednak to nie od języka zależy zdolność teorii naukowej do nawiązania relacji z rzeczywistościa, w tym przewidywania danych zjawisk. Ta relacja zostaje nawiązana przy ustalaniu surowych faktów i stąd jest obecna w teorii. Surowe fakty ustalają więc podwójną relację: między ciałami jako elementami rzeczywistości oraz między podmiotem doświadczającym a doświadczaną rzeczywistością. Oczywiście zły dobór języka czy wybór nieistotnych faktów może utrudnić lub nawet uniemożliwić wejście $\mathrm{w}$ relację z rzeczywistościa, nie generuje jednak tej rzeczywistości ${ }^{22}$.

Każde prawo szczegółowe zawsze jest tylko przybliżone. Bierze się ono bowiem z doświadczeń, które mają tylko pewien stopień dokładności. Ponadto, ujęcie (słowami, wzorem) nigdy nie jest zupełne, gdyż nie jest możliwe, aby zawierało wszystkie możliwe warunki, które powodują dany skutek. „Będziemy jednak pewni, że nie zapomnieliśmy o żadnym z tych warunków, wówczas dopiero, gdy opiszemy dla chwili $t$ stan całego wszechświata" ${ }^{23}$. Nie możemy bowiem wiedzieć z góry, które elementy świata mają wpływ na badane zdarzenie. Dlatego prawa nauki opisują czy przewidują zajście danego zjawiska tylko z pewnym prawdopodobieństwem. Jednak z czasem każde prawo będzie, pod wpływem nowych doświadczeń, zastąpione prawem doskonalszym (dokładniejszym). Ten ciąg coraz dokładniejszych praw musi mieć jednak swój kres (niekoniecznie osiągany), bo inaczej nauka stanie się sztucznym tworem, coraz bardziej oderwanym od rzeczywistości. Obserwacja dziejów nauki pokazuje, że istnieją teorie, które coraz dokładniej i dogłębniej penetrują rzeczywistość. Tym samym widzimy, że prawa przyrody (jako całość) nie są przypadkowe, chociaż są takie gdy traktujemy je osobno.

Również to, iż liczba faktów, które są dostępne poznaniu jest (praktycznie) nieskończona, może być argumentem za nieprzypadkowością praw przyrody. Bowiem tylko niektóre z faktów nadają się do tego,

20 Ibidem, s. 143.

21 Ibidem, s. 148.

${ }^{22}$ Myślę, że analizowany przez Poincarégo układ surowych faktów pokrywa się z bazą empiryczną teorii (pojęcie wprowadzone później przez Poppera) jako wybranym konwencjonalnie układem zdań, z którymi konfrontujemy hipotezy.

23 Ibidem, s. 160. 
by stać się wartościowym materiałem badań naukowych. Ponadto tylko fakty powtarzalne mogą być poddawane procedurze weryfikacji. Trzeba więc dokonywać wyboru. Zauważmy, że największą szansę na powtarzalność mają fakty proste. A proste wydaje się to, co jest „nieskończenie" małe (wyjaśnianie przez całość) lub „nieskończenie” wielkie (wyjaśnianie przez składniki elementarne). Ponadto fakt naukowy powinien być faktem regularnym, a więc uczony dąży do ustalenia reguł, do których dane fakty się stosują. Równie ważne są jednak wyjątki pokazujące granicę stosowalności danych faktów. Te wyjątki uczą że stosowalność danych reguł jest tylko „lokalna” i pozwalają na odkrywanie nowych regut, na rozszerzanie obszaru badań naukowych. Ponadto przy dokładniejszym badaniu różnice i rozbieżności często wskazują na głębsze, ukryte podobieństwa, na podobieństwa między regułami. Jednak "celem naszym powinno być wszelako nie tyle stwierdzanie podobieństw i różnic, ile raczej odnajdywanie utajonych powinowactw pod pozorem obcości" 24 .

Te głębsze podobieństwa są istotnym przedmiotem nauki; a ten wewnętrzny porządek może odkrywać dopiero czysty umysł (piękno i ład materialny dostrzegany jedynie przez zmysły ma dużo mniejsze znaczenie $w$ nauce). Nie jest to jednak odwracanie się od rzeczywistości - wręcz przeciwnie - poszukiwanie piękna intelektualnego sprawia, że umysł nie poddaje się pod dyktat krzykliwych wrażeń zmysłowych i, będąc wolny, odkrywa kolejne obszary rzeczywistości. Na tym polega siła dziedzictwa Greków, że otwiera się na prawdziwą rzeczywistość, a nie na jej zaprzątające umysł krzykliwe fantomy.

Dla Poincarégo punktem odniesienia dla badania obiektywności nauki jest fizyka matematyczna. Patrzy on na jej obecny stan, dostrzegając jej przesilenie. Następnie bada historię tej dyscypliny naukowej, aby zobaczyć nie tylko gotowy gmach (który wymaga remontu i przebudowy), lecz również rusztowania i narzędzia, które służyły i służą do jej budowy. To pozwala na ewentualne skonstruowanie nowych narzędzi potrzebnych do dalszych prac. I w ten sposób można przewidzieć przyszłość fizyki matematycznej rozpoczynając pracę w ramach nowej fizyki.

Jednym z argumentów za obiektywnością nauki jest fakt, że umożliwia ona komunikowanie się między uczonymi i tworzy wspólnotę myśli - tylko to jest obiektywne, co jest wspólne wielu umysłom. Świat uczuć i myśli drugiego człowieka jest przed nami zamknięty. Jednak słowa i znaki, którymi opisuję doświadczaną rzeczywistość mogę komunikować drugiemu (mowa staje się więc warunkiem koniecznym obiektywności). To, co nazywam odnosi się do moich odczuć jak i do rzeczywistości i podobnie jest $\mathrm{z}$ drugim człowiekiem. I właśnie ten stosunek między impresjami jest możliwy do komunikowania. W końcu

${ }^{24}$ H. Poincaré, Nauka i metoda, op. cit., s. 10. 
harmonijne zestawienie różnych stosunków wywołuje w nas impresję piękna i świadomość poznania rzeczywistości. „Zbiorowisko zupełnie nieuporządkowane nie miałoby żadnej wartości przedmiotowej, albowiem byłoby niezrozumiałe, lecz zbiór dobrze uporządkowany może również być pozbawiony wartości, skoro nie odpowiada czuciom rzeczywiście doznanym" 25 .

Poincaré wskazuje na absurdalność argumentu przeciwko obiektywności nauki, który stwierdza, że nauka nie może być obiektywna, gdyż bada jedynie stosunki między rzeczami. Rzeczy, które poznajemy uzyskują rangę obiektywną (zostają nazwane przedmiotami) nie dlatego, że są zbiorem impresji, lecz ponieważ łączą je w całość stosunki między jego elementami. Pozorny argument przeciwko obiektywności nauki staje się dla Poincarégo głównym argumentem za jej obiektywnością.

W oparciu o charakterystykę obiektywności nauki można określić czym jest sama nauka. Jest ona zestawianiem i klasyfikacją faktów, dostrzeganiem ich ukrytych podobieństw, układem stosunków. „Jedynie w stosunkach należy szukać przedmiotowości; nadaremnie szukalibyśmy jej w samych rzeczach uważanych jako wzajemnie odosobnione" ${ }^{26}$. Te stosunki odkrywane w nauce mają bowiem cechy stałości. Nauka nie odkrywa więc istoty rzeczy, lecz prawdziwe stosunki między rzeczami. „Jeżeli mianowicie pewna teoria zapoznała nas z prawdziwym jakimś stosunkiem, sam ten stosunek będzie raz na zawsze zdobyty i odnajdziemy go, acz pod osłoną nowej szaty w innych teoriach, które kolejno zamiast tamtej panować będą" ${ }^{27}$. Jako przykład podaje Poincaré przejście od falowej teorii światła Fresnela do elektromagnetycznej Maxwella. „Teoria falowań eteru mówiła nam, że światło jest ruchem; obecnie moda popiera teorię elektromagnetyczna, według której światło jest prądem" 28 . Mimo całkiem innych teorii i innego języka opisującego światło, w teorii Maxwella zachodzą te same stosunki między prądami hipotetycznymi, co między ruchami hipotetycznymi w teorii Fresnela. Stara teoria nie została więc zdetronizowana, tylko częściowo włączona do nowej.

Poincaré rozważa dwa zdania (a) „Ziemia się obraca" oraz (b) „Dogodniej jest przyjąć, że Ziemia się obraca". Przyjmuje on, że sens tych zdań jest taki sam. Jak pogodzić to stwierdzenie z uznaniem przez niego obiektywności nauki?

Założenie obrotu dziennego Ziemi ukazuje związek między następującymi zjawiskami: pozorny ruch gwiazd, spłaszczenie Ziemi na bie-

\footnotetext{
25 Ibidem, s. 171.

26 Ibidem, s. 172.

27 Ibidem, s. 173.

28 Ibidem, s. 173-174.
} 
gunach, wirowanie cyklonów, obrót wahadła Foucault. Dla zwolenników hipotezy Ziemi nieruchomej te zjawiska nie mają ze sobą związku, ich połączenie jest czysto przypadkowe. Jeśli przyjmiemy, że nie istnieje przestrzeń absolutna (a tak zakłada Poincaré), to wówczas zdanie (a) ma taki sam stopień pewności jak jego zaprzeczenie $\neg$ (a) (możemy znaleźć argumenty potwierdzające tak jedno jak i drugie zdanie). Okazuje się jednak, że przyjęcie zadania (a) daje znacznie więcej interesujących konsekwencji (niż przyjęcie zdania $\neg(\mathrm{a})$ ), ma znacznie większą moc eksplanacyjną i ukazuje związki między zjawiskami - ma więc większą wartość niż zdanie $\neg$ (a). Ponieważ zdanie (a) staje się wspólną przyczyną wielu pozornie różnych zjawisk i odkrywa istnienie między nimi ścisłych związków, a przyjęcie hipotezy $\neg$ ( a) nie pozwala na takie odkrycie, to dogodniej jest przyjać, że Ziemia się obraca (odsłania się w pełni sens zdania (b)). Mimo, iż nie jesteśmy w stanie stwierdzić, które ze zdań (a) czy $\neg$ (a) jest prawdziwe lub fałszywe, to jednak większy związek z rzeczywistością ma zdanie (a) i dzięki przyjęciu założenia (a) możemy tę rzeczywistość badać. Hipoteza (a) prowadzi nas więc do prawdy, a hipoteza $\neg$ ( a) nie daje takiej możliwości ${ }^{29}$.

\section{Cel nauki. Zwiqzzek matematyki i nauk przyrodniczych}

Na pierwszym Kongresie Matematyków, który odbył się w Zurychu w 1897 r., Poincaré wygłosił referat Zwiazek między analiza i fizyka matematyczna. Wskazuje w nim na trzy cele matematyki: czysto przyrodniczy, estetyczny i filozoficzny.

„Matematyka ma cel podwójny. Powinna ona dostarczać narzędzi do badania przyrody. Nie jest to jednak wszystkim; ma ona bowiem ponadto cel filozoficzny i, jeżeli wolno mi tak powiedzieć, cel estetyczny. Powinna ona pobudzać filozofa do zgłębiania pojęć liczby, przestrzeni i czasu" ${ }^{\prime 30}$.

Wprawdzie Poincaré utożsamia w tej wypowiedzi cel filozoficzny i estetyczny, myślę jednak, że warto te cele rozróżnić (matematyka realizując cel estetyczny wykracza poza filozofię oraz naukę i staje się rodzajem sztuki).

Jako narzędzie $\mathrm{w}$ badaniach przyrody jest matematyka niezbędna. Dostarcza bowiem naukom przyrodniczym bogaty, precyzyjny i ścisły język, który pozwala ująć różnorodne i skomplikowane zależności

29 Trzeba pamiętać, że dla Poincarégo eter jest fikcją (podobnie jak grawitacja) jest pojęciem pozwalającym na ujęcie pewnych zależności (dopiero one są realne).

${ }_{30} \mathrm{H}$. Poincaré, Sur les rapports de l'analyse pure et de la physique mathematique, w: Verhandlungen des ersten internationalen Mathematiker - Kongresses, Leipzig 1898; tłum. S. Dickstein, Zwiazki pomiędzy analiza i fizyka matematyczna, "Wiadomości Matematyczne" 1897, t. 1, s. 184. 
odkrywane w przyrodzie. Język matematyki tworzył się (i nieustannie rozwija) przez wieki, próbując skutecznie uchwycić różne niuanse myśli, mowy i rzeczywistości materialnej. Gromadzenie bogactwa wrażeń, doświadczeń i danych (tak w wymiarze potocznym jak i tym bardziej naukowym) łatwo przeradza się w odczucie chaosu, który przenika rzeczywistość. A dzięki zastosowaniu matematyki do opisu świata z mienia się postrzeganie przyrody. Ujęta $w$ ramy ogólnych formuł staje się harmonijnym układem zjawisk. Według Poincarégo tym narzędziem służącym do matematyzacji świata jest analogia matematyczna.

„Kto nauczył nas poznawania analogii prawdziwych, głębokich, których oczy nie widza, a które rozum odgaduje? Jest to duch matematyczny, który gardzi materią a przywiązuje się tylko do formy czystej"31.

Dzięki analogii matematycznej dostrzegamy podobieństwo między zdawałoby się bardzo różniącymi się rzeczami, łączymy nicią rozumienia odległe obszary. Zagrożeniem dla pracy uczonego jest koncentracja na korzyściach i bezpośrednich zastosowaniach. Wówczas analogia matematyczna szybko traci swą siłę - ogólności i prostoty.

Matematyka rozwijała się też w dużej mierze koncentrując się na samym pięknie i prostocie formuł, dowodów i ukazywanych zależności. Była swoistą sztuką dla sztuką i nauką dla nauki. Ten sposób działania stworzył z niej doskonałe dzieło sztuki i pozwolił na odkrywanie głębokiej harmonii charakteryzującej rzeczywistość i wskazał na niepojęty związek rzeczywistości i myśli.

„Cel fizyki matematycznej nie polega jedynie na tym, aby ułatwić fizykom obliczanie numeryczne pewnych stałych lub całkowanie pewnych równań różniczkowych, lecz również, i nade wszystko, aby zapoznać fizyka z ukrytą harmonią rzeczy, ukazując mu je w nowym oświetleniu"32.

Jednak istnieje też oddziaływanie w drugą stronę - rzeczywistości na matematykę. Matematyk nie może zapominać o istnieniu świata zewnętrznego, gdyż odkrywane przez niego piękno właśnie w przyrodzie realizuje się w sposób modelowy i najpełniejszy. "Jakkolwiek urozmaiconą byłaby wyobraźnia ludzka, przyroda jest tysiąckrotnie bogatszą jeszcze [...]. Ze symbolami matematycznymi rzecz ma się podobnie jak z rzeczywistością fizyczną; li tylko przez porównanie różnych stron rzeczy możemy zrozumieć wewnętrzną ich harmonię"33.

Poincaré podaje kilka przykładów korzystania przez matematyków ze struktur dostrzeganych w świecie zewnętrznym. Bez kontaktu z tym światem nie byłoby możliwe podjęcie badań nad wielkościami ciągłymi i nieskończonymi (impulsem była struktura continuum fizycznego),

31 Ibidem, s. 186.

32 H. Poincaré, Wartość nauki, op. cit., s. 94.

33 Ibidem, s. 95. 
znów zagadnienie fizyczne dotyczące przewodnictwa ciepła stało się impulsem do badań szeregów Fouriera, rozszerzenia pojęcia funkcji, a badania równań różniczkowych cząstkowych drugiego rzędu uzyskały swoje szczególne znaczenie dzięki zagadnieniom z teorii elektryczności i teorii ciepła.

Fizyka nie tylko otwiera dla matematyki nowe obszary badań, lecz również dostarcza jej sugestie rozwiązań pewnych zagadnień i metody dowodowe. Problemem wydaje się to, iż ścisłość rozumowań stosowanych w fizyce jest inna (mniejsza) niż ścisłość matematyczna. Są więc jakby dwa rodzaje ścisłości w naukach matematyczno-przyrodniczych. "Zdawałoby się, że nie może być dwóch gatunków ścisłości, że ścisłość jest lub że jej nie ma, i że tam, gdzie jej nie ma, nie może też być rozumowania. Pozorny ten paradoks zrozumiemy lepiej, skoro przypomnimy sobie, w jakich warunkach liczba stosuje się do zjawisk przyrodzonych" ${ }^{\prime 34}$. Dzięki rozluźnionym rygorom ścisłości w fizyce można łatwiej dostrzec mechanizmy pewnych rozumowań, gdyż są one tylko przybliżone. Można jednym spojrzeniem dostrzec to, do czego przy pomocy czystej matematycznej dedukcji dochodzilibyśmy długo i mozolnie. Daną prawdę, zanim udowodni się ją matematycznie, można zobaczyć w świecie fizyki.

\section{Piękno i harmonia w nauce. Nauka wobec piękna i harmonii świata}

Podstawowym przewodnikiem w pracy uczonego i warunkiem umożliwiającym działalność naukową jest poczucie harmonii świata ${ }^{35}$. Ten wewnętrzny zmysł piękna i harmonii jest łącznikiem między światem naszych myśli a rzeczywistością materialną.

Tym samym piękno (jego obecność w teoriach naukowych) jest też dla Poincarégo podstawowym kryterium określającym wartość nauki. Odnajdujemy je w wielu wymiarach i obszarach naukowej działalności. Ukazuje ono przede wszystkim sens nauki w jej teoretycznych i praktycznych badaniach połączonych w sposób nierozerwalny. „Czy przyrodą rządzi kaprys, czy tez panuje w niej harmonia? - oto pytanie; piękno nauki polega właśnie na tym, że ujawnia nam ona tę harmonię, i przez to zasługuje na to, aby ją uprawiać. A jedyną drogą do tej harmonii jest zgodność teorii z doświadczeniem. Celem naszym jest przeto zbadanie, czy zgodność ta zachodzi czy nie. Skoro tak, tedy każda z obu części,

34 Ibidem, s. 99.

$35 \mathrm{Na}$ temat roli piękna w tworzeniu i konstrukcji nauki u różnych uczonych z przełomu XIX i XX wieku pisze Katarzyna Dąbrowska, Czy nauka może być piękna? Status i rola wartości estetycznych w nauce, "Annales Universitatis Mariae Curie-Skłodowska" 2010, Lublin, vol. XXXV, z. 2, s. 31-40. 
które mamy ze sobą porównywać, jest zarówno niezbędną. Zaniedbać jedną dla drugiej byłoby nonsensem. Odosobniona, teoria byłaby próżna, doświadczenie - krótkowzroczne; i jedna i drugie byłoby bezużyteczne i pozbawione interesu" ${ }^{\prime 36}$. Rozrywając więc więź teorii i praktyki niszczymy wartość nauki; natomiast podstawowym zadaniem filozofii jest ukazywanie piękna nauki, czyli ukazywanie głównie istoty i przykładów tej więzi.

Wskazuje się najczęściej dwa (nieco opozycyjne) cele nauki: użyteczność (ułatwienie życia) lub uczynienie człowieka lepszym. Żaden z tych celów nie zadowala Poincarégo. Cel główny (który kieruje nami przy wyborze faktów godnych badania) to poznawanie ukrytego piękna, harmonii świata. To instynktowne pragnienie piękna sprawia, że uczony jeszcze chętniej poszukuje prawdy. Zauważa piękno prostych faktów i formuł matematycznych, piękno ogromu świata i jego odległej przeszłości i pragnie połączyć to w jednej spójnej i harmonijnej teorii. Okazuje się, że „bezinteresowne poszukiwanie prawdy dla jej piękna również jest zdrowe i również zdolne zrobić człowieka lepszym" ${ }^{\prime 37}$. Również użyteczność przychodzi jakby sama jako owoc tego poszukiwania. „I troska o piękno prowadzi do tego samego wyboru, co troska o użyteczność" ${ }^{38}$.

Prawdziwa twórczość naukowa sprzężona jest z tą ukrytą harmonią świata. Na przykład zdolność przeprowadzania dowodów matematycznych opiera się poczuciu ogólnego biegu rozumowania, nie najważniejsza jest pamięć (jak w grze w szachy) czy biegłość rachunkowa, lecz intuicja porządku w jakim elementy tworzące dowód są ułożone. Ta intuicja pozwala odkrywać ukryte harmonie i związki. Działa ona nie tylko w sferze świadomości, bowiem ten porządek świata ma również swoje odzwierciedlenie w pracy podświadomości. „Rozpatruje” ona problemy i kombinacje dowodowe, z którego najprostsze są po jakimś czasie wychwytywane przez świadomość. To zagadnienie podświadomej pracy uczonego bardzo zajmowało Poincarégo, analizował proces dochodzenia do odkryć z wykorzystaniem podświadomości również na swoim przykładzie. Te wszystkie przykłady świadczą o jedności świata, o tym, że wszystkie jego elementy tworzą system wzajemnych relacji i stosunków; dlatego też możliwa jest twórczość i poznawanie świata.

Poincaré, obok matematycznego rozumowania i empirycznego badania świata, traktował intuicję jako kluczowe narzędzie pracy uczonego. Uważał, że nie można jej do końca zastąpić formalnymi operacjami. Dlatego uznawał, że nie jest możliwa redukcja matematyki do logiki formalnej. Nie wystarczy mechaniczne zebrać różne fakty czy dane i wyprowadzić z nich wszystkie możliwe wnioski (w sposób poprawny

36 H. Poincaré, Nauka i metoda, op. cit., s. 209-210.

37 Ibidem, s. 12.

38 Ibidem, s. 11. 
logicznie i spójny). Kluczowy jest wybór odpowiednich hipotez, teorii, zagadnień i faktów, które uznajemy za ważne, które zaspakajają nasze poczucie piękna i które odkrywają ukrytą harmonię rzeczywistości.

\section{Nauczanie matematyki - ciągłość przekazu myśli}

Według Poincarégo głównym celem nauczania matematyki jest kształtowanie umysłu, a wśród jednym z ważniejszych zdolności umysłowych jest intuicja intelektualna. Dzięki niej matematyka utrzymuje kontakt z rzeczywistością a symbol matematyczny odzwierciedla w sobie jakąś część rzeczywistości. Szczególnie w przypadku ludzi stosujących matematykę w praktyce potrzebny jest szybki wgląd w całość zagadnienia. Również nauczanie matematyki musi opierać się na ukazywaniu zasad oraz intuicji, na których wspiera się matematyka. W każdym przypadku, nawet w przypadku czystej matematyki, nie wystarczy zdolność sprawnego dowodzenia i łączenia faktów matematycznych, trzeba posiadać zdolność wybierania najwłaściwszych układów, dowodów i kombinacji. Nie każdy fakt matematyczny ma taką samą wartość, nie każdy dowód będzie uznany jako piękny i przydatny dla rozwoju matematyki.

Do kształtowania intuicji całości (dowodu, rozumowania, układu definicji) niezmiernie przydatna jest historia matematyki, kiedy badamy jak dane pojęcia, dowody i metody rodziły się, zaczynając od intuicji i ogólnych schematów i dochodząc do coraz większej ścisłości i precyzji. Ważny jest dobór odpowiednich przykładów, gdzie można będzie pokazać jak przebiega rozumowanie matematyczne, bez zabijania pierwotnej intuicji zbyt szybko wprowadzanymi wymogami logicznej ścisłości. Nie znaczy to jednak, że mamy zapomnieć o ścisłości w nauczaniu. „Dobra i tęga logika powinna i nadal być jego podstawą. Definicja przez przykład jest zawsze potrzebna, lecz powinna ona przygotować definicję logiczna, nie powinna jej zastąpić; powinna przynajmniej budzić jej potrzebę ${ }^{\prime 39}$. Wszelkie jednak nowinki naukowe, nie mówiąc o rewolucjach, powinny być wprowadzany do nauczanie stopniowo. Ciągłość nauczania i przekazu ma wartość nadrzędną wobec podążania za modą i tak zwanym postępem. Wprowadzanie gwałtownych zmian do systemu nauczania niszczy wartość wychowawczą tworzonej i prezentowanej budowli.

39 Ibidem, s. 106. 


\section{Konwencjonalizm Poincarégo jako próba wyjaśnienia możliwości poznawczych nauki}

Uwagi i rozważania zawarte $\mathrm{w}$ poprzednim rozdziale są tylko przeglądem najważniejszych elementów określających ideę naukowości Poincarégo, będących pewnym ogólnym spojrzeniem na naukę, którą badał i tworzył ten uczony. Próbował on jednak, poza luźnymi uwagami nad nauka, stworzyć system filozoficzny, który wyjaśniałby mechanizmy rozwoju nauki, jej możliwości poznawcze i spójność w sytuacji kryzysu jaki w jego czasach przeżywała. Dlatego rozpoczął budowę teorii filozoficznej, nazwanej konwencjonalizmem (a później realizmem strukturalnym), obejmującej tak samą matematykę, jak i nauki przyrodnicze.

Warto zauważyć, że jego filozofia jest kontynuacją filozofii nauki (a właściwie programu badawczego w naukach) jaką wcześniej zaproponowali Bernard Riemann i Felix Klein.

W projekcie Riemanna trzy nauki - fizyka, psychologia i biologia mają podstawowe znaczenie dla poznania świata. Prawa tych nauk tworzą trójkąt zależności, którego spoiwem są struktury matematyczne. Prawa każdej z tych trzech nauk są jedynie hipotezami (jest to wiedza prawdopodobna). Po dopełnieniu ich formami matematycznymi (i ukazaniu pełnego systemu wzajemnych zależności) możemy otrzymać prawa przyrody. Dla Riemann zasady mechaniki Newtona są hipotezami, jednak w ówczesnym stanie rozwoju nauki możliwe je sformułowanie zależności charakteryzujących się pewnością. Do tego konieczne jest jednak ukazanie odpowiednich analogii między prawami biologii, psychologii oraz fizyki, poprzez wykorzystanie matematyki. Pojęcie analogii jest dla Riemanna kluczowe (podobnie jak dla Poincarégo). Dotyczy ona samych nauk, nauk i filozofii oraz różnych obszarów i poziomów rzeczywistości. Granicą stosowania analogii jest możliwość wykorzystania do budowy tych analogii struktur matematycznych. Rola matematyki w budowie jednolitej wiedzy jest podwójna. Pokazuje stopień ogólności, od której możliwe jest doświadczanie i badanie świata oraz określa maksymalną prostotę praw przyrody (poprzez ujęcie ich w proste formuły matematyczne $)^{40}$.

Natomiast F. Klein, w ramach badań podstaw nauki, sklasyfikował geometrię $\mathrm{w}$ oparciu o niezmienniki odpowiedniej grupy przekształceń przestrzeni (jest to tak zwany program erlangeński). Przykładowo, geometria euklidesowa bada niezmienniki izometrii (czyli przekształceń zachowujących odległość).

40 Projekt Riemanna opisałem w artykule Bernarda Riemanna projekt nowej filozofii, „Kwartalnik Historii Nauki i Techniki” 2007, s. 51-74. 
Poincaré podjął pracę w ramach tych programów. Poszukiwał głębokich analogii w przyrodzie i w świecie nauki i uznał, że kluczowe w budowaniu jedności nauki, świata myśli i rzeczywistości jest pojęcie grupy oraz niezmiennika. Proces poznawania przebiega w oparciu o te pojęcia (stanowią one formę poznania), które "preegzystują w umyśle ludzki$\mathrm{m}^{\prime \prime 4}$. Konkretne doświadczenia zmysłowe „uruchamiają" tę strukturę grupy. Do najbardziej podstawowych należy istnienie ciał sztywnych oraz możliwość kompensowania ruchu tych ciał dzięki zdolności poruszania się $e^{42}$. Według Poincarégo nie doświadczamy przestrzeni fizycznej, jedynie reakcję naszego ciała na ruchy. Przestrzeń euklidesowa jest tworzona $w$ naszym umyśle $w$ oparciu o doświadczenie istnienia ruchów sztywnych i możliwość ich kompensowania. Nie mogłaby ona powstać bez tego doświadczenia. W oparciu o inny zestaw doświadczeń mogłaby powstać inna geometria. Geometria jest więc ściśle związana z naszymi doświadczeniami zmysłowymi, a tworzona jest przy pomocy apriorycznej struktury grupy. Widzimy więc, co znaczy, w rozumieniu Poincarégo, że geometria jest konwencjonalna. Wbrew nazwie jej aksjomaty i twierdzenia nie są całkowicie arbitralne, chociaż element wyboru odgrywa zasadniczą rolę. Ten wybór zależny jest tak od doświadczeń empirycznych, intuicji uczonego, jak również od struktur apriorycznych (zawartych w umyśle, ale również ukształtowanych przed tradycję i wspólnotę uczonych). Jednak ani elementy aprioryczne, ani empiryczne nie determinują geometrii. Argumentem za pierwszym jest istnienie geometrii nieeuklidesowych, natomiast za drugim jest fakt doświadczania nie gotowej struktury przestrzeni geometrycznej, lecz różnorodnych relacji między ciałami.

Poza pojęciami grupy oraz niezmiennika kolejnym elementem apriorycznych struktur poznawczych jest zasada indukcji matematycznej. Można ją nazwać zasadą indukcji apriorycznej, ponieważ ma ona znaczny stopień ogólności i oprócz wspomnianej indukcji matematycznej obejmuje wiele innych operacji myślowych nieskończonych, na przykład zasadę ciągłości, zasadę graniczną czy definicje rekurencyjne.

Jak zauważyliśmy przestrzeń euklidesowa jest najprostszą przestrzenią geometryczną naszego doświadczenia. Można jednak przyjąć inna, szerszą geometrię (wtedy grupa izometrii byłaby jej podgrupą). Żadna z tych geometrii nie jest prawdziwa (lub fałszywa), tylko mniej lub bardziej dogodna. Żadne doświadczenie nie jest też w stanie ich obalić. Za kontakt $\mathrm{z}$ doświadczeniem praw geometrii odpowiada ich forma matematyczna i kryterium prostoty. De facto związek z doświadczeniem

${ }^{41}$ H. Poincaré: La science et l'hypothèse; przekład M.H. Horwitza, Warszawa 1908, s. 77.

42 J. Vuillemin, Poincaré's Philosophy of Space. Space, Time and Geometry, D. Reidel Publishing Company, Dordrecht-Holland 1973, s. 159-177. 
ma miejsce na poziomie struktury grupy i zasady indukcji apriorycznej (Poincaré uznaje je za sądy syntetyczne a priori w sensie Kanta), która dopuszcza różne geometrie. Jednak najprostszą z nich jest geometria euklidesowa i to jest argumentem dla Poincarégo, aby nie rezygnować z niej w opisie świata.

Czy geometria wyraża więc pewną obiektywną treść (poza jej strukturą algebraiczną)? Poincaré zauważa, że argumentem za jej obiektywnością jest fakt przekładalności twierdzeń jednej geometrii na drugą. Pojawiają się niezmienniki tych przekładów np. pojęcie linii geodezyjnej, które w geometrii euklidesowej oznacza linię prostą. Ta wspólna treść musi się wiązać z pewnymi obiektywnymi własnościami przestrzeni fizycznej ${ }^{43}$.

W przypadku teorii fizycznych konwencjonalizm Poincarégo jest koncepcją bardziej złożoną i można nazwać go konwencjonalizmem wyrafinowanym. Najlepiej widać jego specyfikę w zestawieniu z konwencjonalizmem Pierre Duhema. Dla Duhema w fizyce nie ma czystych faktów, dopiero stworzona teoria pozwala pewne fakty widzieć i poddawać je interpretacji. Doświadczenie nie może zaprzeczyć pojedynczej hipotezie, gdyż jest ona częścią teorii i to w nią całą uderza ewentualny kontrprzykład. Dlatego sprawą konwencji jest w jaki sposób będziemy modyfikować teorię (nie samą hipotezę). Hipoteza fizyczna nigdy nie może osiągnąć statusu niepodważalnej prawdy ${ }^{44}$. Dlatego teoria fizyczna jest tylko symbolicznym obrazem rzeczywistości. Dzięki symbolice matematycznej, w jakiej zapisuje się obserwacje, osiąga ścisłość, jednak przez to traci kontakt z rzeczywistością - jej prawa są tylko przybliżone. Fakty nie mogą wejść tak naprawdę w konflikt z teoria gdyż są na różnym poziomie istnienia. Tym samym sprzeczność (pozornie między teorią a faktami) jest sprawą teorii, i sprzeczność tę zawsze zabiegami formalnymi możemy usunąćct

Przede wszystkim Poincaré, w odróżnieniu od Duhema, nie przeciwstawia pewności matematyki przybliżonemu charakterowi teorii fizycznej. Traktuje matematykę i fizykę jako nie dające się rozdzielić dziedziny badań przyrody. „Fizyka matematyczna i analiza czysta nie są tylko potęgami graniczącymi ze sobą [...] lecz przenikają się wzajemnie"46. Pokazanie ścisłych relacji między metodami matematyki i fizyki stanowi wartość dodaną - połączone w ten sposób nauki matematycz-

43 A. Lubomirski, Henri Poincaré'go filozofia geometrii, PWN, Warszawa 1974.

44 Por. P. Duhem, Quelques réflexions au sujet de la physique expérimentalem, „Revue des Questions scientifiques" 1894, 2 ; tłum. M. Sakowska, w: K. Szlachcic, Filozofia nauki francuskiego konwencjonalizmu, Wrocław 1994.

${ }_{45}$ Porównanie koncepcji francuskich konwencjonalistów ma miejsce m.in. w pracy: M. Kotowski, Konwencjonalizm a realizm: Poincaré $i$ Duhem wobec statusu poznawczego nauk przyrodniczych, "Przegląd Filozoficzny” 2016, t. 99, r. 25, nr 3, s. 103-118.

46 H. Poincaré, Sur les rapports de l'analyse pure et de la physique mathematique, s. 184. 
no-przyrodnicze uzyskują wyjątkową siłę i skuteczność. Ponadto, nie uważa, aby teoria fizyczna była jedynie symbolicznym obrazem rzeczywistości.

Kluczem do zrozumienia filozofii nauki Poincarégo jest stosowane przez niego pojęcie "analogii matematycznej” (jest to wpisanie się w program Riemanna). Dzięki niej odległe zdawałoby się rzeczy stają się jednym bytem. W prostej formule analogii $\frac{a}{b}=\frac{b}{c}$ matematyka pełni rolę elementu $b$ (a więc spoiwa rzeczywistości). Natomiast elementy $a$ i $c$ odpowiadają bazie empirycznej - element $a$ temu, co stało się podstawą doświadczalną do sformułowania danego prawa, a element $c$ odpowiada tym elementom doświadczenia, którym dane prawo jest później poddawane. To matematyka uzgadnia te dwa rodzaje doświadczeń.

„Prymitywne prawo wyraża relację pomiędzy dwoma surowymi faktami $A$ i $B$; pomiędzy te dwa surowe fakty wprowadzamy pośrednie pojęcie oderwane $C$, mniej lub więcej fikcyjne (takim była w poprzednim przykładzie nieuchwytna istota grawitacji). A wtedy mamy relacje pomiędzy $A$ i $C$, którą możemy uważać za ścisłą i która jest zasadą; i drugą pomiędzy $C$ i $B$, która pozostaje prawem podlegającym rewizji" ${ }^{47}$.

W podanym przez Poincarégo przykładzie (prawo grawitacji Newtona) tym oderwanym pojęciem stało się pojęcie grawitacji. Tym prymitywnym (pierwotnym) prawem byłoby prawo mówiące, że (1) gwiazdy stosują się do prawa Newtona. Możemy je rozłożyć na prawa, w którym pojawia się pojęcie grawitacji: (2) grawitacja stosuje się do prawa Newtona oraz (3) grawitacja jest jedyną siłą oddziaływującą na gwiazdy. W tym przypadku (2) jest tylko definicją która nie może zostać zmieniona przez doświadczenie, natomiast za kontakt z doświadczeniem odpowiada prawo (3). W swoim pierwotnym ujęciu prawo Newtona stwierdza, że między gwiazdami działa siła, która jest wprost proporcjonalna do masy tych ciał, a odwrotnie do kwadratu ich odległości. Po prowadzeniu pojęcia grawitacji prawo to zostaje opisane przez prosty matematyczny wzór $F_{g}=G \frac{m_{g} M}{r^{2}}$, który wprowadza pojęcie masy grawitacyjnej $m_{g}$, siły grawitacyjnej, oraz stałej grawitacyjnej $G$ (jako stałej uniwersalnej). Ten wzór jest zarazem definicją tych nowo wprowadzonych pojęć przy pomocy fikcyjnego pojęcia grawitacji.

Zauważmy, że to "fikcyjne" pojęcie grawitacji, a de facto struktura matematyczna, łączy też ze sobą pozornie odległe fakty, na przykład fakt spadku swobodnego ciał w kierunku środka Ziemi oraz fakt ruchu Księżyca wokół Ziemi (i wiele innych faktów). Nauka nigdy więc nie

47 H. Poincaré, La valeur de la science, Paris 1961 ; tłum. I. Bukowski, w: K. Szlachcic, Filozofia nauki francuskiego konwencjonalizmu, Wrocław 1994, s. 86-87. 
traci kontaktu z rzeczywistością. Wprawdzie prawo Newtona staje się nierozdzielnie związane $\mathrm{z}$ pojęciem grawitacji w przyjętej formule (i staje się przez to zasadą), jednak zawsze możemy poszukiwać innych sił działających na ciała (masy - niekoniecznie grawitacyjne).

Konwencjonalne ustalenie zasady w sensie Poincarégo jest więc wyodrębnieniem niezmiennika, który nie podlega rewizji doświadczenia. $\mathrm{W}$ rozwoju nauki istotne znaczenie ma wydobywanie z rzeczywistości niezmienników (matematycznych struktur), które pozwalają zarazem na dalsze badanie rzeczywistości i poszukiwanie nowych zjawisk i niezmienników.

Spójrzmy teraz dokładniej na proces ewolucji praw fizyki w rozumieniu Poincarégo. Na prawo fizyki oddziałuje kilka elementów: doświadczenie empiryczne, struktura matematyki, relacje z innymi obszarami nauki, intuicja uczonego i współpraca uczonych. To wszystko sprawia, że prawo fizyki podlega ewolucji. Niektóre (nieliczne) prawa stają się na pewnym etapie rozwoju zasadami, a więc konwencjami w sensie Poincarégo. To, że stają się nieczułe na doświadczenie nie jest tylko efektem umowy między uczonymi, lecz jest wypadkową wielu czynników. Najważniejszymi są: optymalne nasycenie bazą empiryczną oraz prosta i dogodna forma wyrażona w języku matematycznym. Odnaleziona prosta forma matematyczna ujmuje niezmienne stosunki między badanymi zjawiskami. Zasada jednak może nie działać w innych obszarach rzeczywistości - mogą to być obszary jeszcze nie odkryte. Podobnie ma się sprawa z pewnikami geometrii euklidesowej (są one konwencjami w sensie Poincarégo) - nie mogą być podważone przez doświadczenia wzięte z dziedziny geometrii płaskiej. W innej dziedzinie mogą jednak istnieć inne geometrie (nieeuklidesowe), w których tamte pewniki nie obowiązują.

Kiedy następuje uznanie danego prawa za zasadę (konwencję)? Uczeni uznaja, że kolejne doświadczenia mogę jedynie ją potwierdzić, a ewentualne niezgodności będzie można usunąć przez modyfikację innych, związanych z tą konwencja, praw. Istotnym argumentem za podjęciem takiej decyzji jest prostota zasady, jej praktyczna użyteczność (dogodność) oraz piękno matematycznych formuł (w których jest wyrażona) i spójność współtworzonej przez nią teorii. Te składniki tworzące zasadę fizyki sprawiaja, że konwencjonalizm Poincarégo staje się filozofią o wyraźnym zabarwieniu pitagorejskim.

Należy zauważyć, że zasada fizyki w sensie Poincarégo nie jest pojedynczym prawem, lecz nieustannie ewoluującym ciągiem praw. Prawo fizyki $f_{n}$ poprzez kontakt z doświadczeniem, jest przeformułowywane $\mathrm{W}$ doskonalsze i dogodniejsze prawo $f_{n+1}$. W ten sposób powstaje potencjalnie nieskończony ciąg praw $f_{1^{\prime}}, f_{2^{\prime}} f_{3^{\prime}}$. . Istotne jest to, iż zawsze istnieje możliwość korekty prawa tak, aby zachować jego zgodność z doświadczeniem. W pewnym momencie ewolucji prawa można uznać, 
że forma i treść prawa osiągnęły optimum. To wiąże się z podjęciem przez uczonych (konwencjonalnej) decyzji o nie poddawaniu tego prawa dalszemu sprawdzaniu empirycznemu. Ten nieskończony ciąg $\left\{f_{n}\right\}$ staje się zasadą fizyki w sensie Poincarégo. Jest ona strukturą zależną od kilku Elementów: $b$ (baza empiryczna), $p$ (prostota), $m$ (formalizm matematyczny), $d$ (dogodność) oraz $k$ (decyzja konwencjonalna), czyli $\mathrm{z}=\mathrm{z}(b, p, m, d, k)$.

Jak zauważa Poincaré uzyskanie statusu konwencji może dotyczyć tylko niewielkiej liczby praw (gdyby ich było zbyt wiele nauka stałaby się nominalistyczna) i jest dla prawa fizyki nobilitujące. Rozumienie konwencji wykracza poza klasyczny podział sądów w filozofii nauki. Konwencje nie są bowiem ani sądami empirycznymi, ani analitycznymi, ani syntetycznymi priori. Konwencji nie przysługuje cecha prawdy ani fałszu. Jednak to dzięki ich obecności w nauce teoria może być prawdziwa (jako całość) lub zbliżać się do prawdy (gdy patrzymy na nią lokalnie, $\mathrm{w}$ trakcie powstawania).

\section{Spór o fizykę zasad}

Pojęcie niezmiennika odgrywa kluczową rolę nie tylko jako aprioryczna struktura poznania. Jest też kluczem do uchwycenia samej koncepcji konwencjonalizmu (jak mogliśmy wcześniej zauważyć). To pojęcie występuje co najmniej $w$ trzech różnych sytuacjach badania struktury nauki i jej rozwoju. Po pierwsze szukamy niezmienników w ewolucji praw przyrody. Mimo powstawania kolejnych praw, niektóre zależności i struktury starych teorii możemy odnaleźć w nowych. Ten niezmiennik uzyskuje z czasem status zasady fizyki - konwencji. Drugie wykorzystanie pojęcia niezmiennika pojawia się, gdy badając przyrodę, wyniki różnych eksperymentów uogólniamy do praw przyrody. Elementem umożliwiającym to uogólnienie (a więc niezmiennikiem między różnymi eksperymentami) okazują się odpowiednie struktury matematyczne. Trzecią sytuacją jest pojawienie się niezmiennika pomiędzy intuicją odkrywającą ukrytą harmonię rozumowania (piękno dowodu), a ukrytą harmonią porządkiem świata. Ten niezmiennik odnosi się do pojęcia prawdy.

Zgodnie $\mathrm{z}$ konwencjonalizmem Poincarégo formułowanie zasad fizyki jest wyodrębnianiem z rzeczywistości niezmienników i jest to zarazem ukazywaniem matematycznych struktur tejże rzeczywistości. Poincaré badając sytuację w fizyce przełomu XIX i XX wieku zauważa, że uznawane do tamtej pory zasady fizyki zostały poddane w watpliwość przez nowe eksperymenty. Rozważa on czy należałoby bronić tych zasad za wszelką cenę, czy jednak zmienić zasady albo wręczyć zrezygnować z fizyki zasad i budować całkiem nową fizykę, w której podsta- 
wowym narzędziem badań będzie statystyka. Te rozważania sugeruja, że nie traktował swojej filozofii (zasady fizyki jako konwencje są niepodważalne) w sposób aprioryczny. Widział możliwość jej modyfikacji pod wpływem doświadczeń.

Szczególnie wiele wysiłku i miejsca poświęca zasadzie względności. Chce, aby uzyskała status konwencji. Wobec doświadczeń, które nie były w stanie wykryć ruchu Ziemi względem eteru (a tym samym względem absolutnej przestrzeni), jest status wydawał się umocniony. Poincaré obawiał się, że pojawią się nowe eksperymenty, które jednak ją podważą. Natomiast przedwczesne przyjęcie jej jako zasady-konwencji mogłoby zablokować przyszłe próby budowy jednolitej nowej fizyki. Jak wiadomo w 1905 r. Albert Einstein ogłasza swoją szczególną teorię względności, w której przyjmuje dwie zasady w sposób aprioryczny: zasadę względności głosząca, że wszystkie prawa przyrody są jednakowe dla wszystkich obserwatorów poruszających się ruchem jednostajnym prostoliniowym oraz zasadę stałości prędkości światła w próżni. Dziesięć lat wcześniej w 1895 Poincaré zastanawia się nad koniecznością przyjęcia uniwersalnej zasady względności ${ }^{48}$ (po raz pierwszy wprowadził pojęcie zasady względności), a w roku $1898^{49}$ rozważa przyjęcie założenia, że prędkość światła jest stała dla wszystkich obserwatorów. Poincaré traktuje teorię względności jako jedną z alternatywnych teorii i rozważa inne, według niego lepsze możliwości. Nie zgadza się też na przedwczesne uznanie zasady względności jako zasady-konwencji, mogącej być fundamentem nowej teorii. Zasada-konwencja wyłania się stopniowo, w ciągłym dialogu z rzeczywistością. W latach 1905-1908 buduje teorię elektronu, w oparciu o przekształcenia Lorentza ${ }^{50}$ (zauważył, że przy pewnej modyfikacji tworzą one grupę przekształceń). Starał się nadać zasadzie względności maksymalnie ogólny charakter, a jego teoria miała wyjaśniać tak zjawiska elektrodynamiczne jak i mechaniczne. Traktuje pojęcie ruchu jako pojęcie pierwotne, a jego sens jest określony przez grupę przekształceń Lorentza ${ }^{51}$. W teorii elektronu prędkość światła w próżni (jako stała) pojawia się jako parametr w równaniach. W przypadku teorii Einsteina postulat względności nie uzyskuje tak

48 H. Poincaré, À propos de la théorie de M. Larmor, "L'éclairage électrique" 1895, t. 5, s. 14 .

49 H. Poincaré, La mesure du temps, "Revue de métaphysique et de morale“1998, t. 6, s. 1-13.

50 H. Poincaré, Sur la dynamique de l'electron, „Compt. Rend.”1905, t. 140, s. 1504-1508; H. Poincaré, Sur la dynamique de l'electron, „Rendiconti Circolo math., di Palermo" 1906, t. 21, s. 139-176.

51 Z zasadą względności Galileusza związana jest grupa przekształceń Galileusza, określających zmianę współrzędnych położenia i prędkości przy przechodzeniu pomiędzy układami inercjalnymi. Podobnie z zasadą względności proponowanej przez Poincarégo związana jest grupa przekształceń Lorentza. 
uniwersalnego charakteru jak u Poincarégo. Einstein zauważa, pisząc o swojej teorii: „,szczególna teoria względności nie odbiega od klasycznej mechaniki przez postulat względności, lecz przez postulat o stałości prędkości światła w próżni, z którego, w połączeniu ze szczególną zasadą względności, wynika w dobrze znany sposób względność równoczesności, transformacje Lorentza oraz prawa względności dotyczące zachowania się poruszających się ciał i zegarów" ${ }^{\prime 52}$.

Przyjęte rozwiązanie wydaje się Poincarému bezpieczniejsze, gdyż obawiał się, że mogą zostać odkryte prędkości przekazu sygnałów większe od prędkości światła. Tymi wątpliwościami dzieli się na Międzynarodowym Kongresie Sztuk i Nauk w St. Louis w $1904^{53}$. Ponadto priorytetem dla niego było utrzymanie jedności fizyki, a szczególna teoria względności wyraźnie jej zagrażała. Od czasów pracy E.T. Whittakera z 1953 A History of the Theories of Aether and Electricity, w której podważył on wkład Poincarégo w powstanie szczególnej teorii względności, trwa nieustający spór na ten temat. Ten spór opisałem w pracy Polemiki wokót wkładu Poincarégo na powstanie szczególnej teorii względności ${ }^{54}$ z 1993, natomiast jedną z najnowszych prac ukazujących ciągle toczące się dyskusje o to, kto jest autorem szczególnej teorii względności jest artykuł Henri Poincaré: The Movie. The Unintended Consequences of Scientific Commemorations ${ }^{55}$. W sporze, po obu stronach, pojawiają się ciągle nowe argumenty i wydaje się, że dopiero radykalna zmiana w samej fizyce mogłaby go zakończyć. Zgodnie z obawami Poincarégo fizyka nie obroniła (czy nie uzyskała) jedności po wprowadzeniu nowych rozwiązań zaproponowanych przez Einsteina. Współczesna fizyka, składająca się z kilku odrębnych obszarów, nie funkcjonuje zgodnie z ideą naukowości Poincarégo. Nie umie znaleźć bowiem relacji między elementami badanymi w tych obszarach (przykładowo między mechaniką kwantową a mechaniką relatywistyczną), a zgodnie $\mathrm{z}$ koncepcją Poincarégo tylko $\mathrm{w}$ takich relacjach odsłania się realny i obiektywny świat. Trudno też powiedzieć czy propozycja unifikacyjna Poincarégo (budowy teorii elektronu) okazałaby się skuteczna.

52 A. Einstein, Bemerkungen zu der Notiz von Herrn Paul Ehrenfest: Die Translation deformierbarer Elektronen und der Flachensatz, "Annalen der Physik” 1907, t. 23, s. 206.

53 H. Poincaré, L'etat actuel et l'avenir de la psyhique mathematique, w: W. Kruczek, Literatura źródłowa do Kursu "Podstawy fizyki na Politechnice Warszawskiej”, t. 3, Warszawa 1981, s. 264-265.

54 W. Wójcik, Polemiki wokót wkładu Poincarégo, op. cit.

55 Y. Gingras, The Movie. The Unintended Consequences of Scientific Commemorations, "Isis" (2007), nr 98, s. 366-372. 


\section{Bibliografia}

Dąbrowska K., Czy nauka może być piękna? Status i rola wartości estetycznych w nauce, "Annales Universitatis Mariae Curie-Skłodowska” 2010, t. XXXV.

Duhem P., Quelques réflexions au sujet de la physique expérimentalem , „Revue des Questions scientifiques" 1894, nr 2 ; tłum. M. Sakowska, w: K. Szlachcic, Filozofia nauki francuskiego konwencjonalizmu, Wrocław 1994.

Einstein A., Bemerkungen zu der Notiz von Herrn Paul Ehrenfest: Die Translation deformierbarer Elektronen und der Flachensatz, "Annalen der Physik” 1907, t.23.

Gingras Y., The Movie. The Unintendet Consequences of Scientific Commemorations, „Isis” 2007, nr 98.

Gray J., Henri Poincaré. A Scientific Biography, Princeton University Press, Princeton, Oxford 2013.

Grünbaum A., Geometry and Chronometry in Philosophical Perspective, University of Minnesota Press, Minneapolis 1968.

Heinzmann G., Stump D,, "Henri Poincaré", The Stanford Encyclopedia of Philosphy (Spring 2017 Edition), Edward N. Zalta (ed.), https://plato.stanford.edu/archives/spr2017/entries/Poincaré.

Kotowski M., Konwencjonalizm a realizm: Poincaré i Duhem wobec statusu poznawczego nauk przyrodniczych, „Przegląd Filozoficzny” 2016, t. 99, r. 25, nr 3.

Lubomirski A., Henri Poincaré'go filozofia geometrii, PWN, Warszawa 1974.

Poincaré H., À propos de la théorie de M. Larmor, „L'éclairage électrique” 1895, t. 5 .

Poincaré H., La mesure du temps, „Revue de métaphysique et de morale”1998, t. 6.

Poincaré H., Nauka i metoda, tłum. M. H. Horwitz, Warszawa 1911.

Poincaré H., Sur la dynamique de l'électron, "Compt. Rend." 1905, nr 140.

Poincaré H., L'etat actuel et l'avenir de la psyhique mathematique, w: W. Kruczek, Literatura źródłowa do Kursu "Podstawy fizyki na Politechnice Warszawskiej", t. 3, Warszawa 1981.

Poincaré H., Sur la dynamique de l'électron, „Rendiconti Circolo math. di Palermo" 1906, nr 21, 139-176 (1906).

Poincaré H., Sur les hypothèses fondamentales de la géométrie, „Bulletin de la Société Mathématique de France" 1887, t. 15.

Poincaré H., Sur les rapports de l'analyse pure et de la physique mathematique, w: Verhandlungen des ersten internationalen Mathematiker - Kongresses, Leipzig 1898.

Poincaré H., Wartość nauki, tłum. L. Silberstein, Warszawa 1908.

Poincaré H. Zwiazki pomiędzy analiza i fizyka matematyczna, tłum. S. Dickstein,,,Wiadomości Matematyczne" 1897, t. 1.

Quine W.V.O., Ontological Relativity and Other Essays, Columbia University Press, New York 1969.

Quine W.V.O., Pursuit of Truth, Harvard University Press, Cambridge 1990. 
Reichenbach H., H., The Theory of Relativity and A Priori Knowledge, University of California Press, Berkeley 1920.

Sady W., Spór o racjonalność naukową. Od Poincarégo do Laudana, Wydawnictwo Naukowe UMK, Toruń 2013.

Szlachcic K. (red.), Filozofia nauki francuskiego konwencjonalizmu, Wrocław 1994.

Torretti R., Philosophy of Geometry from Riemann to Poincaré, D. Reidel, Dordrecht 1978.

Vuillemin J., Poincaré's Philosophy of Space. Space, Time and Geometry, D. Reidel Publishing Company, Dordrecht-Holland 1973.

Worrall J., Structural Realism, The Best of Both Worlds?, „Dialectica” 1989, nr 43, s. 99-124.

Wójcik W., Bernarda Riemanna projekt nowej filozofii, „Kwartalnik Historii Nauki i Techniki" 2007, r. 52, nr 2.

Wójcik W., Mechanizm ewolucji fizyki wedtug Poincarégo, „Przegląd Filozoficzny" 1993, r. II, nr 4.

Wójcik W., Pewna interpretacja konwencjonalizmu Poincarégo, „Kwartalnik Filozoficzny" 1993, z. 3.

Wójcik W., Polemiki wokót wkładu Poincarégo na powstanie szczególnej teorii względności, "Zagadnienia Filozoficzne w Nauce” 1993, t. XV.

Wójcik W., Różne twarze konwencjonalizmu w kontekście sporu o podstawy szczególnej teorii względności, w: B. Płonka-Syroka (red.), Nauka i społeczeństwo w stulecie szczególnej teorii względności Alberta Einsteina (1905-2005), Wrocław 2006.

\section{Streszczenie}

\section{Idea naukowości Henri Poincarégo}

\section{Słowa kluczowe}

Henri Poincaré; idea naukowości; konwencjonalizm; realizm strukturalny; zasady nauki; zasada względności; kryzys nauki; fizyka zasad; struktury aprioryczne

Henri Poincaré był jednym z ostatnich uczonych mających wgląd w całość nauk matematyczno-przyrodniczych. Czas jego działalności naukowej przypadał na czas przełomu naukowego, kiedy kształtowały się nowe teorie i metody naukowe. W dyskusje filozoficzne nad nauką i jej rozwojem włączyło się wielu uczonych tego okresu. Jedną z ważniejszych koncepcji filozofii nauki, zwaną konwencjonalizmem lub realizmem strukturalnym, stworzył Poincaré. W pracy tej koncentruję się zasadniczo na jednym zagadnieniu - idei naukowości, wypracowanej przez tego uczonego. Wyjaśnię, w jaki sposób jego rozumienie nauki przekracza prostą dychotomię między empiryzmem a racjonalizmem. Ponad- 
to pokażę, że na konwencjonalizm Poincarégo można patrzeć nie tylko jak na pewną teorię filozoficzną lecz również jak na ogólną metodę badawczą.

\section{Summary}

\section{Henri Poincaré's idea of scientificity}

\section{Keywords}

Henri Poincaré; idea of scientificity; conventionalism; structural realism; principles of science; principle of relativity; crisis of science; physics of principles; apriorical structures

Henri Poincaré was one of the last scholars to have an insight into the whole of mathematical and natural sciences. The time of his scientific activities fell during the scientific breakthrough when new theories and methods developed. Many scholars of this period joined the philosophical discussions on science and its development. One of the most important conceptions of the philosophy of science, called conventionalism or structural realism, was created by Poincaré. In this work, I focus on only the one issue - the Poincaré's idea of scientificity. I will explain how his understanding of science transcends the simple dichotomy between empiricism and rationalism. In addition, I will show that Poincaré's convention can be viewed not only as a philosophical theory, but also as a general research method. 